\title{
Production of economic statistics for tourist accommodation services of Belo Horizonte under the flexible geography approach
}

Produção de estatísticas econômicas para os serviços de acomodação turístico de Belo Horizonte sob abordagem da geografia flexível

Caio César Soares Gonçalves

PhD student in Population, Territory and Public Statistics by the National School of Statistical Sciences (Ence) of the Brazilian Institute of Geography and Statistics - IBGE, Belo Horizonte/MG, Brazil

E-mail: caio.goncalves@fjp.mg.gov.br

Article received on: 11-30-2019

Article approved on: 06-30-2020 


\section{ABSTRACT}

This paper aims to produce an experimental economic statistic for the tourist accommodation services for Belo Horizonte under a flexible geography perspective. The starting point is the definition of economic activities in the tourist accommodation concept. The methodology adopted is up-down divided into four steps including filtering processes to accompany the definition, discounts related to obtaining information only for the tourists and procedures for adjustments to the statistics always being compared to the official disclosures and respecting the sum of regions. This analysis revealed an erratic behaviour of the number of establishments in Belo Horizonte across the years and half of the workforce is concentrated in micro and small enterprises. The data from the perspective of the flexible geography allowed to verify where the almost $\mathrm{R} \$ 86$ million indicated by the value added of the tourist accommodations were located in 2015.

Keywords: Economic Statistics. Economic Geography. Accommodation Services. Flexible Geography.

\section{RESUMO}

Este artigo tem como objetivo produzir uma estatística econômica experimental para os serviços de acomodação turística em Belo Horizonte sob uma perspectiva geográfica flexível. O ponto de partida é a definição de atividades econômicas no conceito de acomodação turística. A metodologia adotada é dividida em quatro etapas, incluindo processos de filtragem para acompanhar a definição, descontos relacionados à obtenção de informações relacionadas a apenas para turistas e procedimentos para ajustes nas estatísticas, sempre comparados às divulgações oficiais e respeitando a soma das regiões. Essa análise revelou um comportamento irregular do número de estabelecimentos em Belo Horizonte ao longo dos anos e metade da força de trabalho está concentrada em micro e pequenas empresas. Os dados da perspectiva da geografia flexível permitiram verificar onde estavam localizados os quase $\mathrm{R} \$ 86$ milhões indicados pelo valor agregado das acomodações turísticas no ano de 2015.

Palavras-chave: Estatísticas Econômicas. Geografia Econômica. Serviços de Alojamento. Geografia Flexível. 


\section{INTRODUCTION}

Tourism has been showed rapid and sustained growth in all world in the last decades. In accord World Travels and Tourism Council (2019), the sector grew 3.9\% in 2018 and contributed $\$ 0.8$ trillion of the world economy. It was the eighth consecutive year that the growth of tourism was above the growth rate of the world GDP. World Tourism Organization - UNWTO (2019) shows that international tourism generated 1.7 trillion dollars in exports in 2018. It represented a grew of $4 \%$ in real terms compared with the previous year.

Like these statistics, many methods have been used to analyse tourism activities in an economic view in national, regional and municipal scales. Some authors used Gross Value Added (GVA) estimation (Brazilian Institute of Geography and Statistics - IBGE, 2012; Gonçalves, 2016; Fundação João Pinheiro, 2017), input-output analyses (Casimiro Filho, 2002; Casimiro Filho \& Guilhoto, 2003; Camargo, Takasago, Guilhoto, \& Farias, 2008; Takasago, Guilhoto, Mollo, \& Andrade, 2010), general equilibrium analyses (Takasago \& Andrade, 2008; Fundação Instituto de Pesquisas Aplicadas, 2010; Faria, 2014) and others. All these methods have in common a macro perspective. However, it is interesting also to consider microanalysis under the point of view that tourism is a geographic phenomenon. It means that it happens in some parts of the country or cities.

It is not true that tourism occurs in all parts of a municipality, for example. In the demand side, the tourist will visit some parts of the cities, buy products, and they will consume services in specific areas. In this case, the movement of tourist cannot be generalised for all city. In the supply side, the determination of the locations of the activities related with tourist came from the downtown area, attractive points like historical places, museums, recreational and sport places, beaches, and other natural artefacts. More one time, it cannot be generalised for all the city. However, an exception can be possible when the cities have a vigorous intensity of tourism activity spreads for all space in a city division.

In this way, it became relevant to contemplate aspects from geography in the tourism economics analysis to better represented in statistics the tourism phenomenon.

In many years, the economics did not consider the role of the space in its analysis - the area called economic geography surges to give answers about this absence. In one of its discussions, there is the determination of the location of the economic activities.

Another significant aspect is the scale of the analyses that generally use the political and administrative division to study tourism. The use of different scale, especially the municipality, 
approximates more of the phenomenon. The question is: is it possible to have another type of analysis of tourism under the economic statistics view?

Some geographic analysis utilises the idea of the elimination of the political and administrative division of some phenomenon. The Brazilian Institute of Geography and Statistics (2016) produced the statistics grid of the demographic information of Census for 2010 that consist, for example, presents the population divide in some grades that do not relate with the municipalities or census sectors. In this case, the phenomenon of distribution of the population utilised an analysis on an isonomic scale.

Under this perspective, is considered analysing tourism phenomenon without the political and administrative division. The analysis called flexible geography, different from the statistics grids, produce the statistics with a sum of the area visualised. For example, in some space is plotted the hotels and the number of employees at each point. If the zoom area chooses to visualise seven points, the total of the employees will be the sum of the employees of these seven hotels. However, if the zoom choose appears only two of these seven hotels, the total of employees will be the sum of these just two hotels, and so on. The idea is produced the total indicator number of employees automatically indeed of area choose.

An application of flexible geography has been developed for the production of economic statistics, in specific the gross disposable household income (GDHI), by the Office for National Statistics. As discussed by Fenton, Khatun, Prothero and Chappell (2016), at times of consultation and discussion with users of statistics, there is always a need to produce estimates for other geographical areas that are not contemplated by the Nomenclature of Territorial Units for Statistics (NUTS). It is the case with local government users who always demand information at the local authority level. The difficulty of responding to this type of demand is that, according to Fenton, Khatun, Prothero and Chappell (2016), is the size of the research sample mostly does not produce reliable estimates for small areas.

In addition to NUTS 1, 2, and 3, it is possible to obtain other geographical levels such as the so-called Local Enterprise Partnerships (LEPs) which in England comprise. Some areas that may be fully constituted NUTS areas, some areas that require additional disaggregation at the level of local authorities and, in some cases, smaller areas to provide all the necessary building blocks (Fenton, Khatun, Prothero, \& Chappell, 2016). In this case, the economic variable will be breakdown to small areas or points and then can be sum up by the user according to the demand. In the final phase of the project, will be implementing a flexible geography approach enabling local statistics for any area. 
In the economic tourism, generally, study the tourism characteristics activities (TCA) that includes food and accommodation services, transport services, cultural and recreation services and travel agencies and rental services. In accord with Instituto de Pesquisa Econômica Aplicada (2006) to Brazilian studies, the sectors that more than $70 \%$ of its customers are tourists is the hotel services, air transport services and travel agencies. Between these three, in the study of Fundação João Pinheiro (2017) to the state of Minas Gerais, the accommodation services are the highest value added.

In recent years, Belo Horizonte has changed the profile of business tourism to leisure tourism, and according to Empresa Municipal de Turismo de Belo Horizonte - Belotur (2018), the carnival became one of the most important of the country in the last three years. In this way, this city appears to have a relevant topic of study of its tourism activities.

The goal of this paper is to produce an experimental economic statistic for the tourist accommodation services of Belo Horizonte under the flexible geography approach.

The remainder of the paper is organised as follows. Section 2 describes the idea of the industrial location inside the Economic Geography and the relation with the production of economic statistics. Section 3 presents the methodology and data used defining the concept of tourist accommodation, the procedures of calculation of the economic statistic (value added) and consideration about flexible geography. Section 4 reports the results of the statistic calculated for the tourist accommodation services of Belo Horizonte. Section 5 concludes.

\section{ECONOMIC GEOGRAPHY AND ECONOMIC STATISTICS}

The visualisation of the relevance of space in economic life had already appeared in the late seventeenth century in the studies of the economist William Petty and the engineer Vauban in which they indicated the positive relation of the location of the economic activities in the coastal areas and along the channels and rivers because of the easy navigation. In the eighteenth century, Richard Cantillon addressed the dynamics of wealth production in rural areas and the supply of cities - principles of urban hierarchy discussions. In addition to François Quesnay, he drew economic relations as a circuit, and he is known for publishing the "Tableau économique" in 1758. Between the early nineteenth century and the 1930s, the evolution of the great economic discussions ignored the geographic question. In consequence, it appeared in isolated forms in the literature like the theories of international economic relations, the spacial economy of von Thunen, locational theory of productive activities and economic geography in the nineteen century (Claval, 2005). After that period, the area of Economic Geography arises, and 
as in several areas of science, it presents itself with different approaches using distinct ontological, epistemological and methodological views.

Coe, Kelly and Yeung (2013) presented one of the broad categories of Economic Geography: the positivism. It implied in the use of directed observation and measurement of the phenomena like a method.

After the second war, the social e economic context was different compared to the previous decades. In this time, developed countries were experiencing a positive and sustained growth rate and the intensification of the urbanisation process. In the case of developing countries, they became more independent. Also, the Keynesian style prevailed in the form of governing the national economy.

Thus, the attention of the economic geographers back, as in the colonialism era, to be directed to times and places of housing and work and other issues like the location of the industries.

Moreover, at this time increased the desire for systematic the modes of knowledge production in Economic Geography. The researchers were looking for: (a) seeking universal "laws" or principles that underpinned spatial patterns of economic activity; (b) using quantitative data to identify such patterns; and (c) applying statistical techniques to derive mathematically rigorous proofs of the patterns being identified (Coe, Kelly, \& Yeung, 2013).

It is possible to determine two strands in the quantitative tradition in Economic Geography: one related to spatial analysis using mathematical models and computational techniques for analytical purposes; other focused on integrating space and location inside the neoclassical models of economic theory (Scott, 2000). This second strand is called regional science, and one of the most famous of the area is the Nobel Prize in Economics Paul Krugman (Coe, Kelly, \& Yeung, 2013).

The economist Krugman showed that the industries have a zone of decreasing costs more extensive depending on the places where they installed the factories. The idea is that the places have particularities since that information about the workers, the form of production and other productive aspects are differentiated (Claval, 2005).

In a context in which the rationality used by the economic agents, the decision of the installation location of the industry was strongly related with the cost of the production and the decision rule was the production level that maximises the profits (Claval, 2005). In this way, according to Sampaio (1975), the determination of the ideal location of the industry follows two economic aspects: minimum cost and market area. 
Other discussions about the location of the business to reduce costs appeared in the studies of Johann Heinrich von Thünen in the agricultural land use, originally published in 1826, who was interested in the costs of transport and the role of the distance to determinate the profits (Claval, 2005). This work was rediscovered and used to create models of optimal land-use patterns (Coe, Kelly, \& Yeung, 2013).

Essletzbichler (2011) consider the work of Thünen (1826) the beginning of the location theory. For this author, the location theory is concerned with two characteristics of economic life: distance and area. "It examines how transportation costs, the cost of overcoming distance, affect the price of products and the location of production facilities on the one hand, and the geographic extent of markets on the other" (Essletzbichler, 2011, p. 22).

Another point of view comes from David Ricardo that discuss the role of international trade defending the idea of free commerce, and it like the only and enough possibility of the prices and the factors of production to be equal. However, the evidence showed differently, and the industries concentrated in central areas. A fact easily related to the polarisation theory and with the ideas of Alfred Marshall of scale economies and external economies (Claval, 2005).

Some geographers contributed to this discussion. In according to Claval (2005), Ullman showed that the concentrations of the industries in the central areas are a common feature in the spaces. Stewart and Warntz (YEAR) explained the concentration using the idea of attractiveness caused by potentialities like the potential of the population and the income. Hagerstrand introduced in the analysis that role of the economic information and the relevance of it for the success of the business. Like information is expansive, the places to get free information is in the cities or mainly in the central areas (Claval, 2005).

Ribeiro (1982) mentioned the industrial location theory in four approaches. The first general theory of industrial location is the work produced by Alfred Weber, originally published in 1909. His work was essential to the rise of quantitative Economic Geography.

Weber (1909) studied the industrial location under the point of view of the company that determines the point of least cost of production or optimal location. The main variables in the analysis were the transportation expenses, labour, and agglomeration forces. Thus, the industrial location theory of Alfred Weber focused on the locational decision of the individual firm that happens in a known location environment. Also, this place does not have a dependence on the location of other firms. The second approach addressed the decision of a small group of firms in locationally interdependent. The third one takes into consideration the changes in the real conditions and has a behavioural line (Ribeiro, 1982). 
The central place theory of Walter Christaller, originally from 1933, motivated the construction of models of urban system formation and consumer behaviour. "In this thesis, Christaller posed the following questions: How can we find a general explanation for the sizes, number, and distribution of towns? How can we discover the laws?" (Essletzbichler, 2011, p. 32). Christaller (1933) constructs his theory with the location of retail outlets. Lösch (1954) extends the Christaller central place hierarchy to include agriculture and production activities.

On the other hand, the fourth approach of August Lösch used with the primary variable the market areas. In other words, the general theory of location produced by August Lösch used the demand point of view and so, related more with the examination of any economic landscape (Ribeiro, 1982).

Coe, Kelly and Yeung (2013) pointed out that significant changes to economic geographers should pay attention to new developments in the area, they are: "in global economic power, new forms of global integration, continued dynamism in the development of new technology, and the need to address environmental challenges" (Coe, Kelly, \& Yeung, 2013, p. 513).

In the actual context, the term globalisation describes the intensification of the commercial exchanges associated with productions of good and services in different parts of the world - the flexible production and the reduction of the cost of transport and the facility to transfer information (Claval, 2012).

Carvalho and Filho (2017) synthesise the different approaches of the economic geography like a science since the application of the concept of sight in the agriculture and manufacture, the use of quantitative methods and the location theory, the Marxist and economistic approaches, other alternatives approaches such as institutionalism, feminism, and anti-racism. In the Information Era, the authors pointed out the return of the idea of industrial districts and the flexible regime.

\subsection{Production of economic statistics}

There is no doubt that economic agents need to make decisions based on sound statistical evidence. Whatever the type of statistics used, economical, demographic, or social, they serve to monitor the living conditions of the population and understand society.

In economic statistics, which can be understood as any quantitative information relevant to the public and private sectors used for the analysis of an economic issue, these are fundamental to monitor, understand and manage the economy, being vital for policymakers and 
for private sector decisions to access statistics that must be accurate, reliable, relevant and timely. Also, statistics can be used by the population to obtain information and to hold policymakers accountable for the performance of the economy (Bean, 2016).

The economic statistics that stand out most are those that make up the structure of the National Accounts, developed even in the 1930s and 1940s when the area of macroeconomics emerged. However, many other economic statistics are relevant as prices, wages and balance of payments. In addition, as Bean (2016) adds, it is worth noting that such information is needed at levels below an aggregate economy so much so that, from the point of view of regional policies, information is needed on an economic activity at the regional level corresponding to the application of the policy, for example.

It is on this aspect that public institutions producing these statistics emerge to guarantee the reliable, exempt information that corresponds to the needs of the users, and to present a certain degree of acceptable precision and in a sufficiently timely manner (Bean, 2016). It also emphasises the role that statistical institutions have and should exercise as organs of State, not the government (Senra, 2017).

Of course, this is not an easy task given that a statistic is not a fact. Bean (2016) exemplifies by showing that even when a variable is apparently well defined, as with the total number of people working in a given period, what is behind this statistic is still an estimate as soon as this data is usually generated by sampling the total population, which makes the representativeness of the sample a significant challenge in itself. Even against this and other adversities and even challenges inherent to the type of activity carried out, countries and regions have bodies dedicated to statistical production.

Therefore, statistics play a fundamental role in the knowledge of the socioeconomic reality of a nation besides fostering the areas of public policy decision making. The production of statistics called public statistics or official statistics represents those produced independently and with international standards for comparability and quality assurance.

The study of Bean (2016) produced an independent review of the production of economic statistics produced by the Office for National Statistics (ONS). In this work, presented three main objectives. The first one was the axis of necessity in which the objective was to evaluate the future needs of statistics that the UK could have, in particular, the measurement challenges imposed by the modern economy. Second, the capacity to assess the effectiveness of ONS in the production of economic statistics and including a focus on the use of relevant data and data science techniques. The third one, the governance axis which verifies the independence of the production of statistics in the United Kingdom. 
The result presented by the report pointed to the need for more flexible regional statistics and for different geographic areas, as well as questions about the production of statistics timelier to the current questions. Bean (2016) argued that the statistics produced respond to questions asked more than fifty years ago. Also, it pointed to the greater use of administrative records in the production of statistics.

It is precisely one of the discussions within the area of statistical production, the level of detail of the information and the search for the gradual increase of information for smaller and smaller geographical units.

The Brazilian Institute of Geography and Statistics (IBGE) conducted a study with the availability of demographic census data for 2010 independent of the territorial divisions. The so-called statistical grids were only possible to be realised from the technological advances introduced by the use of electronic equipment in the collection of information, which captures the geographical coordinate in addition to an address register associated with road mapping (IBGE, 2016).

\section{METHODOLOGY AND DATABASE}

Carvalho and Filho (2017) stated about the geography studies of the industry in Brazil; they focused on how the activities evolved and their impact on the transformation of the landscape. For the authors, until the 1970s, there were still no studies that include economics and statistics except exceptions. Much of this was due to the lack of information, and it was necessary to carry out primary research to obtain quantitative and qualitative information that would foster an understanding of the process and the flows of the industry. For those conducting the surveys, these tended to focus on only a single city or industrial district.

According to Ribeiro (1982), the urban industrial researches included in the Brazilian studies different numbers of approaches and scale. In the case of regional level, the Brazilian literature presents location studies, analysis of commodity flows and areas of influence delimitation. In the case of local level as cities and metropolitan regions, the focus was the patterns of location and flows of raw materials and markets.

Carvalho and Filho (2017) mentioned that economic models applied to the location of industries used quantitative methods such as factor analysis and cluster analysis. In the case of the measurement of magnitude and intensity of industrial activity, the variable number of jobs is the most used and accepted. Also, can be used the number of establishments, value added 
and the least used the quantity of energy consumed, industrial earnings, the quantity of raw material used, capital invested in industry and installed industrial capacity.

For the present study, the delimitation of the data obtained is for the level of the municipality of Belo Horizonte in Minas Gerais. The primary variable to be calculated is the value added of tourist accommodation services. For this, it is necessary to define tourist accommodation in terms of economic activities, the definition of procedures for calculation of value added and to delimit the analysis to be presented.

\subsection{Definition of tourist accommodation}

The definition of what services will be considered as tourist accommodation part of the design of Tourism Characteristics Activities (TCA). For the classification of economic activity as a tourism characteristic, the identification of products defined as tourism is used. The World Tourism Organization (UNWTO) has developed the Standard International Classification of Tourism Activities (SICTA) to create uniform international comparisons of statistics.

In Brazil, the classification of economic activity officially adopted by the National Statistical System and by the registers and records of the Public Administration is the National Classification of Economic Activities - CNAE. The Brazilian Institute of Geography and Statistics, in its study on tourism in Brazil, reconciled the Characteristic Activities of Tourism with the CNAE in its most recent version (2.0) (IBGE, 2012).

Table 1 presents a list of activities considered TCA in the present work with their respective subclass CNAE 2.0 codes by hierarchy. It is essential to highlight that in accommodation group is included all types in the tourist concept (hotels, apart-hotels, inns, hostels, campsites, pensions, other lodgings), except motels. 
Table 1 - Classification of Accommodations Activities

\begin{tabular}{l|c}
\hline Hierarchy & Activities CNAE 2.0 \\
\hline Division & 55 Accommodation \\
Group & 55.1 Hotels and similar \\
Class & $55.10-8$ Hotels and similar \\
Subclass & $5510-8 / 01$ Hotels \\
Subclass & $5510-8 / 02$ Aparthotel \\
Subclass & $5510-8 / 03$ Motels \\
Group & 55.9 Other accommodation types \\
Class & $55.90-6$ Other accommodation types \\
Subclass & $5590-6 / 01$ Hostels, except care \\
Subclass & $5590-6 / 02$ Campsites \\
Subclass & $5590-6 / 03$ Pensions (accommodation) \\
Subclass & $5590-6 / 99$ Other accommodation not elsewhere classified \\
\hline
\end{tabular}

Subclass 5590-6/99 Other accommodation not elsewhere classified

Note: * Motels is excluded from the concept of tourist accommodation.

Source: Prepared by the author, 2019.

\subsection{Calculation of value added}

For the calculation of the value added of the tourist accommodation in Belo Horizonte, a sequence of four steps is necessary because to obtain information at an activity level not available and for a geographic level also unavailable. With this, assumptions will be made for an approximation of what would be value added. We opted for the up-down method, where it is estimated first for the most aggregated level to the least aggregated level.

The first step consists in collecting the data available from the National Accounts of IBGE at the level of economic activities, specifically the value added of accommodation at current prices for the years 2010 to 2016 on the Brazil scale. Also, collect in the Rais database the earnings of accommodation activities at the CNAE subclass level to obtain the weight of the motels. The deduction of the weight of the motels applied to the value added of the accommodation generates the value added of the accommodation without motels. From the data of the Ipea, the coefficient of tourist service is obtained, that is, the percentage of the consultations carried out in the accommodation services are with tourists. This coefficient is implicitly calculated from the database of Ipea in the years 2010 to 2016 . When applying this coefficient in the value added of tourism service without motels, one has the value added of tourist accommodation for Brazil in the period from 2010 to 2016.

The second stage begins with the collection of data from IBGE's Regional Accounts that are disclosed to economic activities. However, unlike the National Accounts, accommodation is shared with food services. In order to separate these values, the earnings of the lodging and food services of the Rais base for the years 2010 to 2016 of each unit of the federation is used. After applying this weight, one has the value added to the accommodation per UF. However, the total sum of the units of the federation must be equal to the total of Brazil, in this way, the 
structure is calculated from the value added of the accommodation referred to here as not adjusted. When multiplying this structure by the value added of the accommodation of Brazil of each year, the value added of the accommodation adjusted by UF is obtained. Again, from the Rais database of earnings of subclass activities of accommodation, it is possible to calculate the weight of motels in each unit of the federation. When discounting this weight, obtained the value added of the accommodation without unadjusted motels. The same adjustment procedure with the total value of Brazil is used, and the value added of the accommodation without adjusted motels is obtained. After it follows the discount of the tourist service coefficient. Moreover, finally, the value added of the tourist accommodation is obtained per unit of the federation in the years 2010 to 2016.

The third step consists basically in the repetition of the second stage, considering that the values to be adjusted must be the same as those obtained for Minas Gerais. Another difference is that the municipal GDP database of IBGE presents the opening of activities in only four levels: agriculture, industry, services, and public administration. Therefore, the necessary weight to be obtained based on the Rais base is the size of the earnings of the accommodation about the total of services excluding public administration. From this, the value added of the accommodation is obtained by the municipality, which in the case of Minas Gerais is 853. In the end, one has the value added of tourist accommodation of the 853 municipalities from the years 2010 to 2016 . However, the interest in present work is the values obtained for Belo Horizonte.

The fourth step consists in distributing the value added of tourist accommodation to the local units obtained in the Rais microdata of the year 2015. In this data, it is possible to identify the addresses of establishments that, based on latitude and longitude identification procedures, produce a base of geolocated addresses. The value added distribution rule would be the number of jobs in each establishment.

It is worth mentioning that obtaining the value added of the tourist accommodation in Belo Horizonte in the year 2015 is an approximation of what would be the gains of the establishments with the tourists. As it deals with the application of different databases and draws information to approximate the concept of tourism (motel deduction and resident care), these values do not represent the actual values. Thus, this indicator makes it possible to identify areas where establishments most added the economy in the year 2015. More crudely, it could be said that these are the most profitable areas for formal establishments registered as tourist accommodation. 


\subsection{Flexible geography}

Flexible geography consists of the possibility of obtaining data for understandings of phenomena whose expression does not coincide with political-administrative units or other territorial division traditionally used in the disclosures of official statistical offices. The territorial delimitation becomes the desire of the researcher.

The statistics to be presented under these modifications are usually utilised disaggregations and aggregations procedures. Besides, techniques are necessary for not identifying the information collected directly from the informant. Moreover, depending on the case study, not necessarily the total presents represents the total disclosed, and there may be methodological issues.

In the present work, the adopted view of the idea of flexible geography implements an application that geolocalized local units in the city of Belo Horizonte that the main variable is the value added the of tourist accommodation for the specific year of 2015 .

The built-in application allows the visualisation in a bubble graph style plotted in an interactive map of the value added, showing the areas with the highest value. Statistics are obtained by choosing an area selected by the zoom tool, automatically calculating the sum of the value added for that area viewed.

As the main economic statistics presented here required the disaggregation procedure, it was decided to carry out an analysis using the traditional terrorist divisions to locate the accommodation establishments of Belo Horizonte in relation to the state of Minas Gerais and in relation to Brazil. When it is highlighted, other regions such as comparisons with other Brazilian capitals and other Federative Units may be triggered. It should be emphasised that the information from the Rais establishments database filtered for the concept of tourist accommodation is available for the years 2006 to 2017. The information generated for the value added of tourist accommodation is calculated for the years 2010 to Finally, information for intra-urban analysis is available for the year 2015.

\section{RESULTS}

Since the methods start with the procedures of desegregation of information in politicaladministrative divisions, this section is divided into two parts: the analysis in the macro level with information to Belo Horizonte and the analysis of intraurban areas with flexible geography approach. 


\subsection{Statistics with political-administrative divisions}

In 2017, the number of establishments in Brazil classified as tourist accommodation was 27.778. São Paulo is the unit of the federation that has the most substantial participation. $19,2 \%$ of the accommodation is registered in São Paulo, followed by 12,3\% in Minas Gerais and 9,6\% in Rio de Janeiro. In Belo Horizonte, the number registered was 249 establishments. Belo Horizonte is the fifth capital with the most significant number of accommodations for tourists behind São Paulo, Rio de Janeiro, Florianópolis and Salvador.

The behaviour of the number of establishments over the years varied as well as the variation of the participation of Belo Horizonte in the total of establishments of tourist accommodation in Minas Gerais and Brazil. In 2017, Belo Horizonte presented weight of 0,9\% of the total of this type of establishment in Brazil and 7,3\% in the total of Minas Gerais. About Brazil, this share has already reached 1,1\% between the years of 2006 and 2010, and about Minas, a much more significant variation has already reached the level of $9,1 \%$. Table 2 presents these values.

Table 2 - Number of tourist accommodation establishments and participation in the total of Brazil and Minas Gerais - Brazil, Minas Gerais and Belo Horizonte - 2006-2017

\begin{tabular}{|c|c|c|c|c|c|}
\hline Year & Brazil & Minas Gerais & Belo Horizonte & $\begin{array}{l}\text { Participation in the } \\
\text { total of Brazil }(\%)\end{array}$ & $\begin{array}{c}\text { Participation in the } \\
\text { total of Minas } \\
\text { Gerais }(\%)\end{array}$ \\
\hline 2006 & 19.778 & 2.420 & 221 & 1,1 & 9,1 \\
\hline 2007 & 20.500 & 2.533 & 228 & 1,1 & 9,0 \\
\hline 2008 & 21.266 & 2.644 & 239 & 1,1 & 9,0 \\
\hline 2009 & 22.152 & 2.725 & 233 & 1,1 & 8,6 \\
\hline 2010 & 23.168 & 2.869 & 246 & 1,1 & 8,6 \\
\hline 2011 & 24.277 & 3.035 & 233 & 1,0 & 7,7 \\
\hline 2012 & 25.201 & 3.164 & 261 & 1,0 & 8,2 \\
\hline 2013 & 26.304 & 3.298 & 247 & 0,9 & 7,5 \\
\hline 2014 & 27.337 & 3.410 & 275 & 1,0 & 8,1 \\
\hline 2015 & 27.822 & 3.462 & 260 & 0,9 & 7,5 \\
\hline 2016 & 27.904 & 3.418 & 267 & 1,0 & 7,8 \\
\hline 2017 & 27.778 & 3.413 & 249 & 0,9 & 7,3 \\
\hline
\end{tabular}

It is important to note that the variation in the number of establishments over the years is quite different when comparing the scale levels Brazil, Minas Gerais and Belo Horizonte. Graph 1 illustrates the trajectories and reveals the similar behaviour of Minas Gerais with Brazil. About Minas Gerais, the behaviour is of falls, followed by positive growths. This type of performance becomes evident after 2008, which since then has shown positive growth in even and negative years in odd years. 
Figure 1 - Growth rate of the number of tourist accommodation establishments - Brazil, Minas Gerais and Belo Horizonte - 2007-2017 (\%)

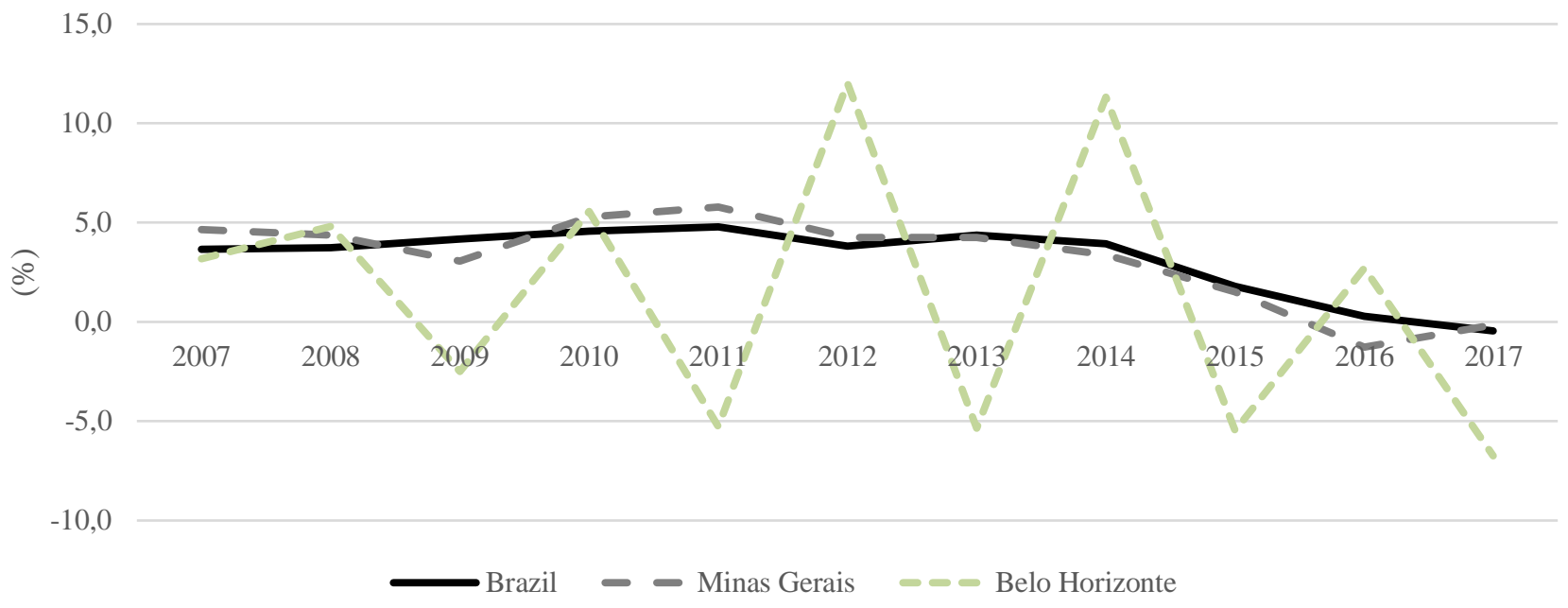

Source: Prepared by the author, 2019.

When selecting the variations over the years of the number of establishments for the Brazilian capitals, it is verified that this erratic behaviour also happens. Moreover, the trend of increasingly negative rates after 2013 is more perceptible. For example, São Paulo presented negative rates in 2009, 2011, 2015 and 2017. Salvador recorded a negative rate in 2011 and 2013 to 2017. In contrast, Florianópolis presented positive rates in 2007, 2010 and from 2012 to 2017 with the growth rate of 5,8\%. Belo Horizonte closed the year 2017 with a decrease of $6,7 \%$ in the number of tourist accommodation establishments.

In terms of the composition of tourist accommodations, it is possible to classify them according to their size and by subclass CNAE 2.0. Table 3 shows the percentage distribution of establishments by size. The classification used for service activities considers a microenterprise that has up to 9 employees, a small one from 10 to 49 employees, medium-sized from 50 to 99 employees and large employees with 100 or more employees. The tourist accommodation establishments of Belo Horizonte are mostly micro-businesses, that is, they have up to 9 employees. An average of 63,6\% in the years 2006 to 2017 were microenterprises, $31,1 \%$ small, $4,1 \%$ midsize and $1,3 \%$ large. 
Table 3 - Percentage distribution of the number of tourist accommodation establishments, by size, Belo Horizonte - 2006-2017 (\%)

\begin{tabular}{ccccc}
\hline Year & micro & small size & midsize & large \\
\hline 2006 & 64,3 & 30,8 & 3,6 & 1,4 \\
2007 & 63,2 & 31,1 & 4,4 & 1,3 \\
2008 & 61,1 & 33,1 & 4,6 & 1,3 \\
2009 & 62,2 & 31,8 & 4,7 & 1,3 \\
2010 & 65,4 & 28,5 & 4,9 & 1,2 \\
2011 & 60,5 & 33,5 & 4,7 & 1,3 \\
2012 & 64,0 & 29,5 & 5,4 & 1,1 \\
2013 & 61,1 & 32,0 & 5,3 & 1,6 \\
2014 & 60,7 & 33,1 & 4,4 & 1,8 \\
2015 & 65,4 & 31,2 & 2,7 & 0,8 \\
2016 & 65,9 & 30,0 & 3,4 & 0,7 \\
2017 & 69,1 & 28,9 & 0,8 & 1,2 \\
\hline
\end{tabular}

Source: Prepared by the author, 2019.

About the types of establishments, the lower level CNAE presents the subclasses hotel, apart-hotel, hostels, boarding houses, and other accommodations. In 2017, most of the types of accommodation in Belo Horizonte are hotels $(58,2 \%)$, followed by boarding houses $(17,7 \%)$ (Table 4).

Table 4 - Percentage distribution of the number of tourist accommodation establishments, by subclass, Belo Horizonte - 2006-2017 (\%)

\begin{tabular}{cccccc}
\hline Year & Hotels & $\begin{array}{c}\text { Apart- } \\
\text { Hotels }\end{array}$ & $\begin{array}{c}\text { Hostels, Except } \\
\text { Assistance }\end{array}$ & $\begin{array}{c}\text { Boarding Houses } \\
\text { (Accommodation) }\end{array}$ & Other Accommodations \\
\hline 2006 & 56,1 & 2,7 & 5,9 & 12,7 & 22,6 \\
2007 & 57,5 & 3,9 & 3,9 & 12,3 & 22,4 \\
2008 & 58,6 & 3,3 & 5,4 & 14,2 & 18,4 \\
2009 & 59,7 & 3,0 & 4,7 & 15,0 & 17,6 \\
2010 & 58,5 & 2,4 & 4,9 & 16,3 & 17,9 \\
2011 & 55,8 & 2,1 & 5,2 & 18,5 & 18,5 \\
2012 & 57,5 & 3,1 & 6,5 & 17,6 & 15,3 \\
2013 & 56,7 & 3,6 & 6,9 & 17,4 & 15,6 \\
2014 & 56,7 & 4,4 & 6,9 & 16,4 & 14,2 \\
2015 & 56,9 & 4,6 & 6,9 & 17,3 & 12,0 \\
2016 & 57,3 & 5,6 & 6,7 & 18,4 & 12,4 \\
2017 & 58,2 & 5,6 & 6,0 & 17,7 & \\
\hline
\end{tabular}

Source: Prepared by the author, 2019.

In specific for the year 2015, table 5 presents the cross-reference of the size information of the establishment and the type by subclass. Through the data, it is possible to visualise that the establishments considered of medium and large size are only the hotels, being registered nine in the year of 2015. Hostels, except assistance, boarding houses (accommodation) and other accommodations are of greater microenterprises. 
Table 5 - Number of tourist accommodation establishments, by subclass and size - Belo Horizonte - 2015

\begin{tabular}{lccccc}
\hline Subclass/Size & Micro & Small size & Midsize & Large & Total \\
\hline Hotels & 83 & 56 & 7 & 2 & 148 \\
Apart-Hotels & 7 & 5 & 0 & 0 & 12 \\
Hostels, Except Assistance & 14 & 4 & 0 & 0 & 18 \\
Boarding Houses (Accommodation) & 37 & 8 & 0 & 0 & 45 \\
Other Accommodations & 29 & 8 & 0 & 0 & 37 \\
\hline Total & 170 & 81 & 7 & 2 & 260 \\
\hline
\end{tabular}

Source: Prepared by the author, 2019.

The analysis of the evolution of the number of jobs is similar to that carried out until then for the number of tourist accommodation establishments. It should be noted that Belo Horizonte, which ranks $5^{\circ}$ in a number of establishments, drops to the twelfth position in the capital ranking for the number of jobs. In 2017, there were 2.843 jobs in Belo Horizonte. The first capital was Rio de Janeiro with 19.492 jobs, followed by São Paulo with 14.876 and Salvador with 5.198 jobs.

Of the total of 2.843 jobs in 2017 of Belo Horizonte, 79,3\% of them were employed in hotels. For the year 2015, this total was $3.365(77,4 \%)$. Table 6 shows the cross-referencing of information between the type of establishment and size. 40,7\% of the jobs are concentrated in small hotels, $10,9 \%$ in micro-enterprises. Large hotels accounted for $13,1 \%$ of total jobs in Belo Horizonte in 2015.

Table 6 - Percentage distribution of the number of jobs of tourist accommodation, by subclass and size - Belo Horizonte - 2015

\begin{tabular}{lccccc}
\hline Subclass & Micro & Small size & Midsize & Large & Total \\
\hline Hotels & 10,9 & 40,7 & 12,8 & 13,1 & 77,4 \\
Apart-Hotels & 0,7 & 3,9 & 0,0 & 0,0 & 4,6 \\
Hostels, Except Assistance & 1,0 & 2,6 & 0,0 & 0,0 & 3,6 \\
Boarding Houses (Accommodation) & 3,6 & 3,3 & 0,0 & 0,0 & 6,9 \\
Other Accommodations & 3,2 & 4,4 & 0,0 & 0,0 & 7,5 \\
\hline Total & 19,3 & 54,8 & 12,8 & 13,1 & 100,0 \\
\hline
\end{tabular}

Source: Prepared by the author, 2019.

When applying the method of calculating the value added of the tourist accommodation services previously presented, Brazil recorded a value added of $\mathrm{R} \$ 8,9$ billion in 2016. In 2014, the year of the World Cup in Brazil, this value exceeds R\$ 10 billion. In Minas Gerais, the value added of tourist accommodation was R $\$ 506$ million in 2016 and Belo Horizonte R \$ 41 million. The participation of Belo Horizonte in the total of Brazil and Minas Gerais varied between 0,5\% to $0,9 \%$ in relation to the total of Brazil and $7,5 \%$ to $14,8 \%$ in relation to the total of Minas Gerais in the period of study (2010-2016) (Table7). 
Table 7 - Value added of tourist accommodation establishments and participation in the total of Brazil and Minas Gerais - Brazil, Minas Gerais and Belo Horizonte - 2010-2016 (R\$ million)

\begin{tabular}{|c|c|c|c|c|c|}
\hline Year & Brazil & $\begin{array}{l}\text { Minas } \\
\text { Gerais }\end{array}$ & Belo Horizon-te & $\begin{array}{c}\text { Participation in the total } \\
\text { of Brazil }(\%)\end{array}$ & $\begin{array}{l}\text { Participation in the total } \\
\text { of Minas Gerais }(\%)\end{array}$ \\
\hline 2010 & 5.591 & 359 & 36 & 0,6 & 10,1 \\
\hline 2011 & 6.207 & 442 & 33 & 0,5 & 7,5 \\
\hline 2012 & 6.618 & 501 & 55 & 0,8 & 11,1 \\
\hline 2013 & 8.618 & 572 & 49 & 0,6 & 8,5 \\
\hline 2014 & 10.109 & 825 & 89 & 0,9 & 10,8 \\
\hline 2015 & 9.693 & 580 & 86 & 0,9 & 14,8 \\
\hline 2016 & 8.939 & 506 & 41 & 0,5 & 8,2 \\
\hline
\end{tabular}

Source: Prepared by the author, 2019.

It is worth mentioning that São Paulo is the federation unit with the highest value added of tourist accommodation, followed by Rio de Janeiro and Bahia. Minas Gerais appears in the fourth position of the value-added ranking in 2016. The municipality of Belo Horizonte surpassed the units of the Rondônia, Piauí, Amapá, Acre and Roraima federations.

\subsection{Statistics with flexible Geography}

In 2015, the value added of tourist accommodation in Belo Horizonte was estimated at 85.548.252 reais. Figure 2 (a) shows a map representing $100 \%$ of the value added. Local units are represented by bubbles that represent the size of value added. The colouring represented indicates the classification by CNAE class of the establishments being the hotels and aparthotels in the colour purple and the other types of accommodation in yellow colour. Figure 2 (a) also shows the feature of decentralisation of the location of the tourist accommodation in Belo Horizonte, especially groups in central area, south, north, and northwest of the map. 
Figure 2 - Map of value added to tourist accommodation - selected area - 2015

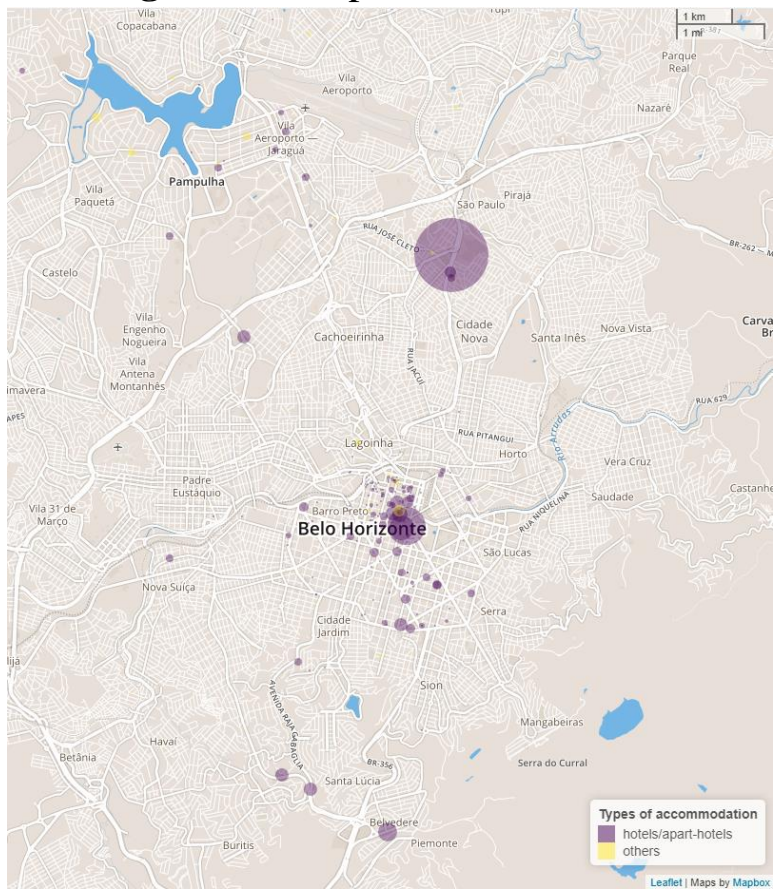

(a) $100 \%$ area

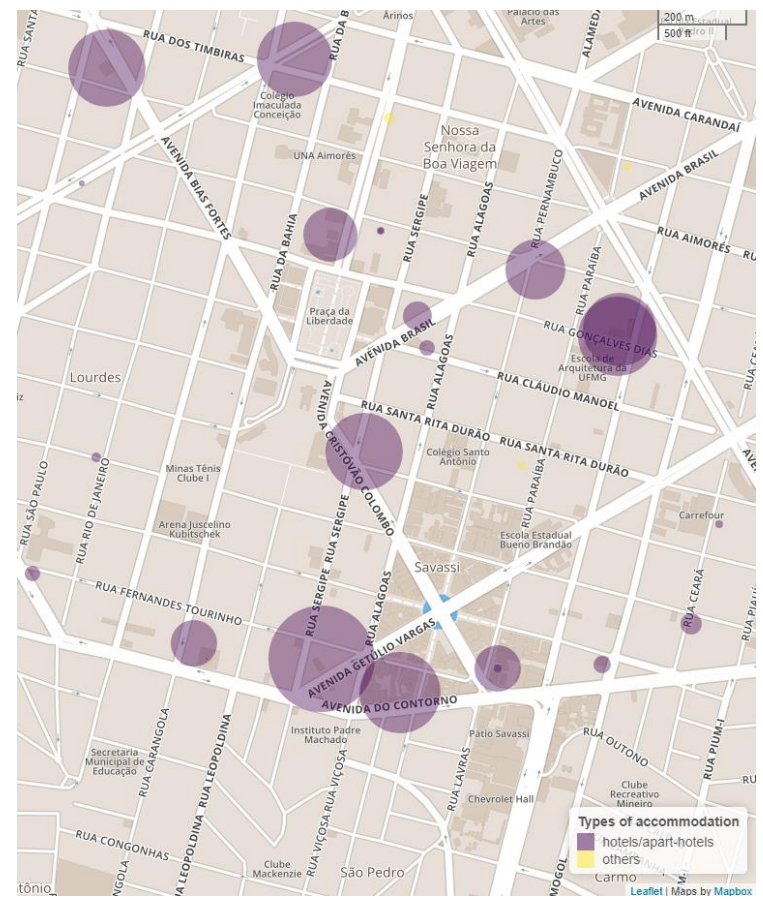

(c) Near Savassi area

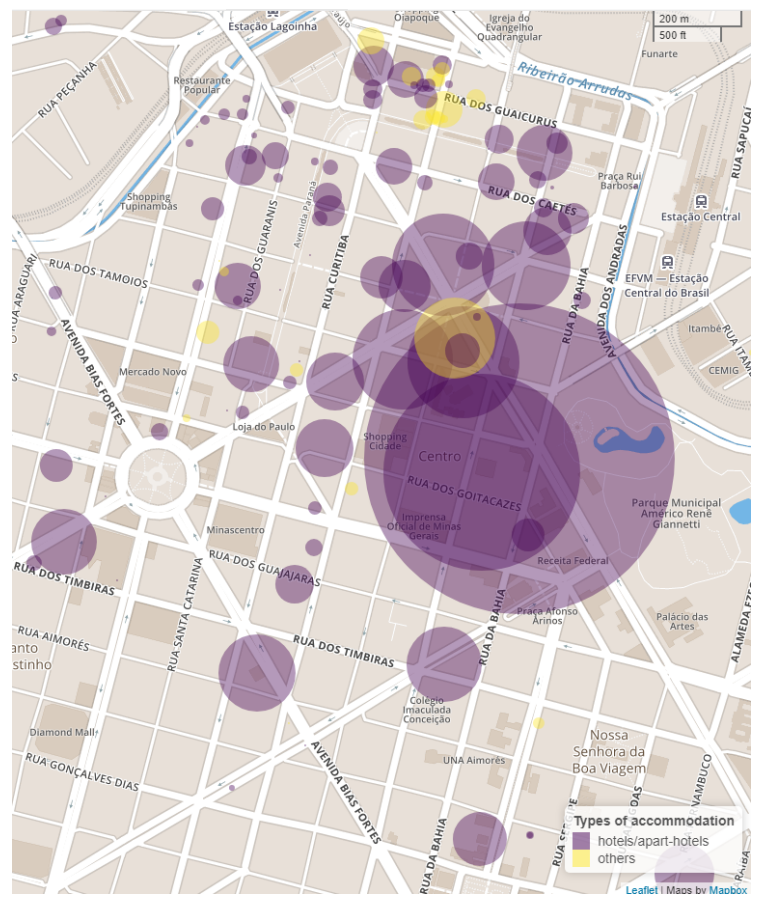

(b) Central area

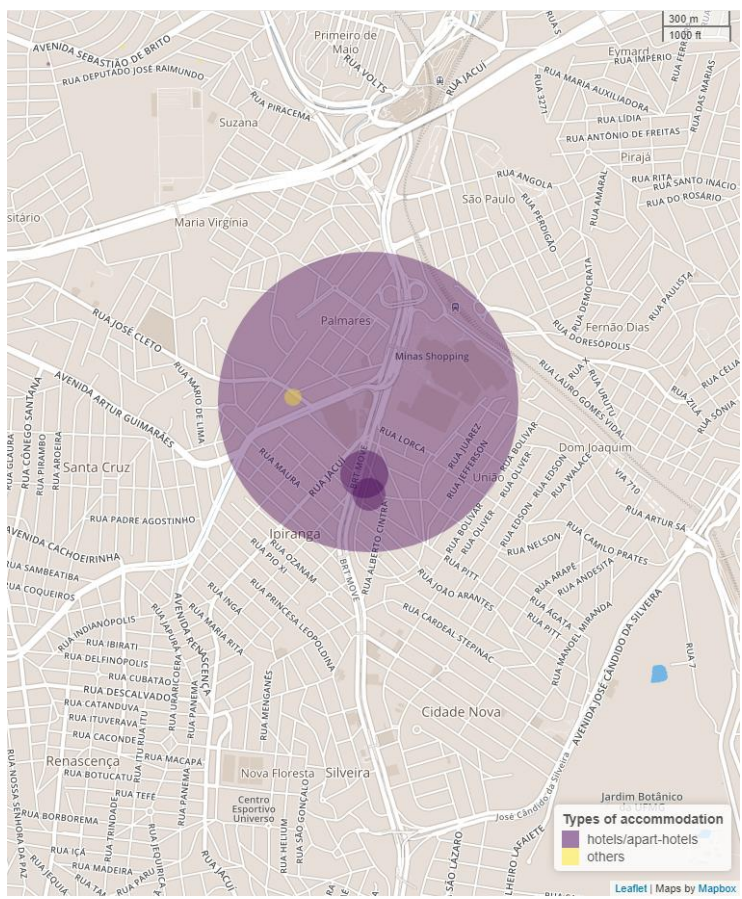

(d) Minas Shooping area

Source: Prepared by the author, 2019.

Figure 2 (b) depicts the central area of Belo Horizonte that concentrates two important subway stations and the bus station of Belo Horizonte. The area represented in the limits of the figure represented an area of $44,1 \%$ of the value added of tourist accommodation, equivalent to 38.245 million reais. 
A region that attracts tourists in Belo Horizonte is the area near the Savassi neighbourhood including the Freedom Square circuit. The area represented by Figure 2 (c) represented around 10 million reais, which represents $11,7 \%$ of the value added of the tourist accommodation of Belo Horizonte in 2015.

The region near Minas Shopping presented the largest hotel establishment and ranked first in the Belo Horizonte ranking. The area corresponding to the map in Figure 2 (d) represents $13,7 \%$ of the total value added. Despite having the first place, the region has a smaller and more isolated number of tourist accommodation establishments.

\section{CONCLUSIONS}

The objective of this paper is to produce an economic statistic for the tourist accommodation services for Belo Horizonte under a flexible geography perspective. This article presented the value added estimates of this type of services, starting with the definition of economic activities include in the tourist accommodation concept. Besides, this present work localised the use of quantitative information as fomenting to understand the location of the industries inside the Economic Geography.

In order to obtain the value added estimates, the procedure adopted was up-down divided into a series of steps with filtering processes to accompany the definition, discounts related to obtaining information only for the tourists and procedures for adjustments to the statistics always being comparative the official disclosures and respecting the sum of regions. Thus, estimates of tourist accommodation services for Brazil, the federative units and all municipalities of Minas Gerais for the years 2010 to 2016.

As the variables of the number of jobs and total earnings were considered as criteria for disaggregation, the present article also presented the analysis of the information about the accommodation establishments of Belo Horizonte as a way to characterise these already existing statistics. This analysis from 2006 to 2017 revealed an erratic behaviour of the number of establishments in Belo Horizonte with a pattern of growth and decrease in consecutive years. Indicating the opening of local units in even years and closing in odd years. In 2014, the year of the world cup in Brazil, the largest number of tourist accommodation services in Belo Horizonte was recorded in the period under study.

The investigation of the size of establishments by type of classification of accommodation services revealed that micro and small companies prevail with a percentage superior to $90 \%$. Hotels represent approximately $57 \%$, and boarding houses on average $17 \%$ in the last years of analysis. Additionally, the companies classified as medium and large are only 
classified as hotels (9 establishments in 2015) that registered almost $26 \%$ jobs. Thus, half of the workforce is concentrated in micro and small enterprises, $10,9 \%$ and $40,7 \%$, respectively.

The information from the perspective of the flexible geography allowed to verify where the almost $\mathrm{R} \$ 86$ million indicated by the value added of the tourist accommodations were located. The vast majority is located in the central area of Belo Horizonte, specifically having as a central axis the intersection of two important avenues of the city: Amazonas Avenue and Afonso Pena Avenue. Also, the region that owns the largest hotel development in the municipality represents around $10 \%$ of the value added.

It is always worth mentioning that the values presented by the value added of the tourist accommodation are an estimate to indicate the areas of most significant gains with tourists. In this specific case, accommodation services are chosen based on the economic activity of greater value and with higher attendance to tourists as identified in the literature. Also, this discussion of the present work is inserted in a field that does not exist economic statistics systematised to levels beyond the municipal and opening of economic activities that surpasses the division between agriculture, industry, and services.

This article achieves its goal of producing experimental economic statistics for a hitherto untapped level. However, it is possible to expand the study presented here to something that uses spatially localised data analysis techniques, for example, spatial statistics and also create mechanisms to control the quality of the geospatial information correlated with the statistics since all the information used in this study were informed in the administrative registers.

\section{REFERENCES}

Bean, C. (2016) Independent Review of UK Economic Statistics. Retrieved June, 23, 2019, from https://www.gov.uk/government/publications/independent-review-of-uk-economicstatistics-final-report

Camargo, F., Takasago, M., Guilhoto, J., \& Farias, A. (2008). O Turismo e a Economia Brasileira: uma discussão da matriz de insumo-produto. In: $14^{\circ}$ Congresso da APDR. Portugal: Tomar, 1-16.

Carvalho, D. R. P., \& Veloso Filho, F. A. (2017). Geografia econômica: origem, perspectiva e temas relevantes. Caderno de Geografia, 27(50).

Casimiro Filho, F. (2002). Contribuições do turismo à economia brasileira. Piracicaba. 220p. Tese de Doutorado, Escola Superior de Agricultura Luiz de Queiroz, Universidade de São Paulo, São Paulo, SP, Brasil. 
Casimiro Filho, F., \& Guilhoto, J. (2003). Matriz de Insumo-Produto para a economia turística brasileira: construção e análise das relações intersetoriais. Análise Econômica, 21(40), 227-263.

Christaller, W (1933). Die zentralen Orte in Süddeutschland. Jena: Gustav Fischer.

Claval. P. (2005). Geografia econômica e economia. GeoTextos, 1(1), 11-27.

Claval, P. (2012). A diversidade das geografias econômicas. Geographia, 14(2), 7-20.

Coe, Neil M., Kelly, Philip F., \& Yeung Henry W. C. (2013). Economic Geography: A Contemporary Introduction. Wiley.

Empresa Municipal de Turismo de Belo Horizonte - Belotur. (2018). Carnaval de Belo Horizonte se consolida como um dos principais do país. Retrieved June, 15, 2019, from belohorizonte.mg.gov.br/sala-de-imprensa/noticia/belo-horizonte-se-consolida-como-um-dosprincipais-carnavais-do-brasil

Essletzbichler, J. (2011). Locating Location Models. In: Leyshon, A; Lee, R.; Sunley, P.; Mcdowell, L. (Orgs.). The SAGE Handbook of Economic Geography. 23-38.

Faria, D. (2014). Turismo cultural y desarrollo regional: la metrópolis como referencia. Periferica, 447-469.

Fenton, T., Khatun, F., Prothero, R., \& Chappell, R. (2016). Supporting devolution: developments in regional and local statistics. Retrieved June, 15, 2019, from https://www.ons.gov.uk/economy/regionalaccounts/grossdisposablehouseholdincome/articles/ supportingdevolutiondevelopmentsinregionalandlocalstatistics/2016-05-25

Fundação João Pinheiro. (2017). Economia do Turismo de Minas Gerais: 2010-2014. Belo Horizonte: FJP.

Fundação Instituto de Pesquisas Econômicas - FIPE. (2010). Estudos de impactos socioeconômicos potenciais dos investimentos do Prodetur Nacional Rio de Janeiro. São Paulo: Relatório Final, março/2010.

Gonçalves, C. (2016). Valor adicionado do turismo de Minas Gerais: um cálculo com os coeficientes de atendimento turístico. Boletim de Conjuntura Econômica de Minas Gerais, 9, 59-71. Retrieved June, 15, 2019, from http://www.fjp.mg.gov.br/index.php/docman/cei/boletim-de-conjuntura/627boletimdeconjuntura1oquadrimestre27-06-2016/file

Instituto Brasileiro de Geografia e Estatística - IBGE. (2012). Economia do turismo: uma perspectiva macroeconômica: 2003-2009. Estudos e Pesquisas. 18. Rio de Janeiro. Retrieved June, 15, 2019, from ftp://ftp.ibge.gov.br/Economia_Turismo/2003_2009/ EcoTurismo2003_2009.pdf

Instituto Brasileiro de Geografia e Estatística - IBGE. (2016). Grade Estatística. Rio de Janeiro.

Instituto de Pesquisa Econômica Aplicada - Ipea. (2006). Metodologia do cálculo dos coeficientes de atendimento turístico e estimativas relativas ao emprego formal no setor do turismo com base nos dados da RAIS. Brasília: Ipea. 
Lösch, A. (1954). The Economics of Location. New Haven, CT: Yale University Press.

Ribeiro, M. A. C. (1982). Principais linhas de abordagem e estudos empíricos a nível intraurbano: uma resenha em torno da localização industrial. Revista Brasileira de Geografia, 44(3), 415-444.

Sampaio, S. S. (1975). Considerações em torno da geografia industrial: teoria, métodos e uma nova técnica de mensuração da atividade fabril. Revista Brasileira de Geografia, 37(1), 95 122.

Scott, A. J. (2000). Economic geography: the great half-century. Cambridge Journal of Economics, 24, 485-504.

Senra, N. C. (2017). Três tempos do sistema estatística e geográfico brasileiro: rumo ao quarto tempo? Boletim de Estatísticas Públicas. Retrieved June, 15, 2019, from http://www.anipes.org.br/wp-content/uploads/2013/09/Anipes-2017-Digital-1.pdf

Takasago, M., \& Andrade, J. (2008). O modelo de Equilíbrio Geral Computável e o turismo no Brasil. Economia do turismo no Brasil. In: A economia do turismo no Brasil. Brasília: SENAC/DF.

Takasago, M., Guilhoto, J., Mollo, M., \& Andrade, J. (2010). O potencial criador de emprego e renda do turismo no Brasil. Pesquisa e Planejamento Econômico - PPE. 40(3), 431-460.

Thünen, J. H. (1826). Der isolierate Staat in Beziehung auf Landwirtschaft und Nationalökonomie. Hamburg: Perthes.

Weber, A. (1909). Alfred Weber's Theory of the Location of Industries. Chicago: University of Chicago Press.

World Travel, \& Tourism Council. (2019). Travel \& Tourism continues Strong growth above global GDP. Retrieved June, 15, 2019, from https://www.wttc.org/about/media-centre/pressreleases/press-releases/2019/travel-tourism-continues-strong-growth-above-global-gdp/.

World Tourism Organization - WTO. (2019). World Tourism Barometer. 17(2). Retrieved June, 15, 2019, from http://cf.cdn.unwto.org/sites/all/files/pdf/unwto_barom19_02_may _excerpt.pdf

\section{FORMAT FOR CITATION OF THIS ARTICLE}

GONÇALVES, C. S. S. (2020). Production of economic statistics for tourist accommodation services of Belo Horizonte under the flexible geography approach. Revista de Turismo Contemporâneo, 8(2), 198-221. https://doi.org/10.21680/2357-8211.2020v8n2ID19375 